Article

\title{
Antimicrobial Activity against Paenibacillus larvae and Functional Properties of Lactiplantibacillus plantarum Strains: Potential Benefits for Honeybee Health
}

\author{
Massimo Iorizzo ${ }^{1}$ (D), Bruno Testa ${ }^{1}$ (D), Silvia Jane Lombardi ${ }^{1}$, Sonia Ganassi ${ }^{1}$, , Mario Ianiro ${ }^{1}$, \\ Francesco Letizia ${ }^{1}$, Mariantonietta Succi ${ }^{1}$, Patrizio Tremonte ${ }^{1}$, Franca Vergalito ${ }^{1}$, \\ Autilia Cozzolino ${ }^{1}$, Elena Sorrentino ${ }^{1}{ }^{(\mathbb{D}}$, Raffaele Coppola $^{1} \mathbb{D}$, Sonia Petrarca ${ }^{2}$, \\ Massimo Mancini ${ }^{1}$ and Antonio De Cristofaro ${ }^{1}$ (D) \\ 1 Department of Agriculture, Environmental and Food Sciences, University of Molise, \\ 86100 Campobasso, Italy; iorizzo@unimol.it (M.I.); bruno.testa@unimol.it (B.T.); \\ silvia.lombardi@unimol.it (S.J.L.); m.ianiro@studenti.unimol.it (M.I.); francesco.letizia@unimol.it (F.L.); \\ succi@unimol.it (M.S.); tremonte@unimol.it (P.T.); franca.vergalito@unimol.it (F.V.); \\ autilia.cozzolino@unimol.it (A.C.); sorrentino@unimol.it (E.S.); coppola@unimol.it (R.C.); \\ maxman@unimol.it (M.M.); decrist@unimol.it (A.D.C.) \\ 2 Consorzio Nazionale Produttori Apistici CONAPROA, 86100 Campobasso, Italy; sonia_petrarca@libero.it \\ * Correspondence: sonia.ganassi@unimol.it
}

Received: 6 July 2020; Accepted: 22 July 2020; Published: 24 July 2020

check for updates

\begin{abstract}
Paenibacillus larvae is the causative agent of American foulbrood (AFB), a severe bacterial disease that affects larvae of honeybees. The present study evaluated, in vitro, antimicrobial activity of sixty-one Lactiplantibacillus plantarum strains, against P. larvae ATCC 9545. Five strains (P8, P25, P86, P95 and P100) that showed the greatest antagonism against $P$. larvae ATCC 9545 were selected for further physiological and biochemical characterizations. In particular, the hydrophobicity, auto-aggregation, exopolysaccharides production, osmotic tolerance, enzymatic activity and carbohydrate assimilation patterns were evaluated. The five L. plantarum selected strains showed suitable physical and biochemical properties for their use as probiotics in the honeybee diet. The selection and availability of new selected bacteria with good functional characteristics and with antagonistic activity against $P$. larvae opens up interesting perspectives for new biocontrol strategies of diseases such as AFB.
\end{abstract}

Keywords: Lactiplantibacillus plantarum; probiotics; Paenibacillus larvae; honeybee

\section{Introduction}

Paenibacillus larvae, the causative agent of the quarantine disease American foulbrood (AFB), is the most widespread fatal brood disease of honeybee (Apis mellifera L.) larvae and pupae [1]. This gram-positive, flagellated, spore-forming bacterium is highly adapted to honeybee larvae [1,2]. The honeybee gut is the site of P. larvae infection, as well as of pathogens such as Ascosphaera apis, Nosema ceranae, and probably many of the honeybee viruses [3]. Following ingestion, through spore-contaminated food, the spores germinate in the larval midgut lumen, where the vegetative bacteria massively proliferate before eventually breaching the midgut epithelium and invading the hemocoel, causing the death of the larvae, which during their decay releases a large number of spores. In the further course of the disease within the colony, more and more larvae become infected and die so that in the end, the lack of brood and, hence, the lack of progeny leads to collapse of the entire colony $[1,2]$. P. larvae often remains dormant in its spore-form and does not induce manifestations 
of AFB. It has been suggested that P. larvae may exist as a pathobiont in the native microbiota of adult worker bees and is then transmitted throughout the hive to fresh brood cells [4]. The extreme contagiousness of AFB and the lethality for larvae and for entire colonies are the reasons why it is a notifiable disease in most countries. Currently, since an effective therapy against AFB is not available, the authorities consider the burning of infected colonies as the only efficient control measure [5]. Over the last few years, a number of different measures such as the use of chemical fungicides, antibiotics, heterocyclic organic compounds (indoles) and bacteriophages have been tried against AFB disease [6-10]. Unfortunately, these approaches could be useful as therapy, but are often ineffective for prophylactic purposes, and hives remain vulnerable to diseases. Moreover, the prophylactic use of antibiotics has inevitably led to the onset of antibiotic resistance in P. larvae [11,12]. In addition, the use of chemical compounds should be limited, both because they are dangerous to honeybee health [13] and because any residues present in honey also pose a serious risk to human health [14]. The use of natural compounds for disease control could represent a more suitable alternative [15,16]. Essential oils and other vegetable extracts from plants, herbs and spices exhibit antimicrobial activity against $P$. larvae $[17,18]$ and this activity is mainly due to the presence of phenolic and terpenoid compounds, which have well-known antimicrobial activity [19-21]. However, the effects of these substances on honeybee health and on its symbiotic microflora are not entirely known [22]. Currently, there is an increased interest in investigating new, effective and safe control methods. In this context, the use of probiotic bacteria in the prevention and biocontrol of honeybee pathogenic microorganisms offers interesting perspectives [23]. The use of probiotic bacteria, unlike synthetic or natural chemical compounds, does not adversely affect the balance of gut microbiota and honeybee health [24,25]. Moreover, the protection against pathogens and/or parasites is one of the aspects frequently associated with a balanced intestinal flora [26-28]. It is well known that the initial phase of pathogen infection can be facilitated by any nutritional or environmental stress causing microbial dysbiosis [29-31]. The presence of lactic acid bacteria (LAB) in the honeybee gastrointestinal tract has been consistently reported in literature [32-34]. Beneficial bacteria, belonging to LAB, have been shown to promote honeybee health through activating the honeybee's immune defenses and producing antimicrobial compounds inhibiting pathogenic microorganisms [35-44]. The antagonistic effects of symbiotic LAB against $P$. larvae can be exploited to develop a new approach to AFB disease control [45-47]. Among LAB, Lactiplantibacillus plantarum (formerly Lactobacillus plantarum) [48] is a versatile bacterium characterized by a high adaptability to many different conditions, being isolated from various ecological niches including dairy, fruits, cereal crops, vegetables, fish and fresh meat [49]. In addition, its presence in honeybee gut has been documented by several researchers [50-52], and its role, along with other bacteria and yeasts, in the transformation of fresh pollen into bee bread is well known [53,54]. L. plantarum pro-technological properties are exploited in different agri-food sectors [55-63]. Moreover, some strains of L. plantarum are known for their ability to produce several natural antimicrobial substances, thus inhibiting competitors that share the same niche [64-69]. The natural genomic architecture is the basis of its versatility and of its success in industrial applications, not only as starter culture but also as a bio-protective agent [70]. However, while numerous data on the functional and probiotic properties of L. plantarum in the diet of fish and mammals, including humans, were obtained [71-75], to our knowledge, its use as a probiotic in the honeybee diet and its antagonistic action against P. larvae has been little studied [76-78]. In this research we investigated the inhibitory properties of L. plantarum strains, isolated, in previous studies [79], from the honeybee (A. mellifera L.) gut and bee bread, against P. larvae ATCC 9545. In addition, some of their functional characteristics have been evaluated for a possible probiotication of the sugar syrups, to be used in the supplemental feeding of honeybees. 


\section{Results}

\subsection{Antimicrobial Activity}

The antagonistic activity, of sixty-one L. plantarum strains, against P. larvae ATCC 9545 was investigated. The results of a preliminary screening, using the agar spot test, showed that thirty-five strains did not cause any inhibition and twenty-one strains caused an inhibition zone (ZOI) $<4 \mathrm{~mm}$. P8, P25, P86, P95 and P100 L. plantarum strains, demonstrating the greatest antagonism against the pathogen (ZOI $>4 \mathrm{~mm}$ ), were selected for the subsequent investigations (Table S1, Supplementary Materials). In this further analysis, the antimicrobial activity was carried out using agar well diffusion assay and the inhibitive capacity was assessed using cultural broth (BC) and cell free supernatants (CFS) of the five selected strains. The results of the antimicrobial activity are reported in Table 1.

Table 1. Antimicrobial activity (inhibition zone $\mathrm{mm}$ ) of L. plantarum strains using cultural broths (BC) and cell free supernatants (CFS). Exopolysaccharides (EPS) amounts $(\mu \mathrm{g} / \mathrm{mL})$ in MRS broth after $48 \mathrm{~h}$ at $37^{\circ} \mathrm{C}$ in aerobiosis. Results are shown as mean \pm standard deviation $(n=3)$. Different uppercase letters (A-D), in each column, and different lowercase letters $(a, b)$, in each row, indicate significant differences $(p<0.05)$.

\begin{tabular}{cccc}
\hline \multirow{2}{*}{$\begin{array}{c}\text { L. plantarum } \\
\text { Strains }\end{array}$} & \multicolumn{2}{c}{ Inhibition Zone $(\mathbf{m m})$} & EPS Production $(\mu \mathrm{g} / \mathrm{mL})$ \\
\cline { 2 - 4 } & BC & CFS & EPS \\
\hline P8 & $7.2 \pm 0.2^{\mathrm{Db}}$ & $5.8 \pm 0.3^{\mathrm{Ca}}$ & $174.0 \pm 6.0^{\mathrm{C}}$ \\
P25 & $6.0 \pm 0.2^{\mathrm{Cb}}$ & $3.7 \pm 0.1^{\mathrm{Aa}}$ & $140.0 \pm 6.0^{\mathrm{B}}$ \\
P86 & $6.1 \pm 0.4^{\mathrm{Cb}}$ & $4.1 \pm 0.3^{\mathrm{Aa}}$ & $167.0^{\mathrm{Ca}} 4.0^{\mathrm{C}}$ \\
P95 & $4.2 \pm 0.3^{\mathrm{Ab}}$ & $3.4 \pm 0.1^{\mathrm{Aa}}$ & $76.0 \pm 3.0^{\mathrm{A}}$ \\
P100 & $5.1 \pm 0.2^{\mathrm{Bb}}$ & $4.6 \pm 0.3^{\mathrm{Ba}}$ & $135.0 \pm 4.0^{\mathrm{B}}$ \\
\hline
\end{tabular}

The BC, of five L. plantarum, inhibited P. larvae more than CFS. In particular, BC caused a ZOI between 4.2 and $7.2 \mathrm{~mm}$ wide, whereas the CFS caused a ZOI between 3.4 and $5.8 \mathrm{~mm}$ wide. The highest inhibitive activity was produced by L. plantarum P8 strain. The MRS broth at pH 3.5, used as control, did not produce any inhibition.

\subsection{Exopolysaccharides Production}

The exopolysaccharides (EPS) amounts, produced by the five L. plantarum selected strains, in MRS broth after $48 \mathrm{~h}$ at $37^{\circ} \mathrm{C}$ in aerobiosis were generally significantly different among them (Table 1). In particular, P95 strain was the lowest EPS producer $(76 \mathrm{mg} / \mathrm{L})$; the other strains produced quantities greater than $130 \mathrm{mg} / \mathrm{L}$ with a maximum of $174 \mathrm{mg} / \mathrm{L}$ produced by the L. plantarum P100 strain.

\subsection{Cell Surface Properties: Hydrophobicity and Auto-Aggregation}

The hydrophobicity was assessed using the ability of the bacteria to adhere to toluene and xylene hydrocarbons. The results of the hydrophobicity (\%) of the five L. plantarum selected strains are reported graphically in Figure 1 and numerically in Table S2 (Supplementary Materials). For each strain, the bacteria adhesion to the two hydrocarbons was similar and increased gradually during the test period (60 min). P8 and P25 strains, already after $15 \mathrm{~min}$, showed a high adherence to toluene and xylene with a hydrophobicity percentage greater than $90 \%$, and after $60 \mathrm{~min}$, the percentage was around $99 \%$. P86 and P95 strain adherence rates, after $60 \mathrm{~min}$, were less than 60\% both to xylene and toluene. P100 strain showed the lowest hydrophobicity with adherence values less than $40 \%$, to both hydrocarbons, after $60 \mathrm{~min}$.

The auto-aggregation (AA\%) was assessed by measuring the optical density decrease of the five Lactiplantibacilli cultures suspended in phosphate saline buffer (PBS). The analyses showed that the ability to aggregate and sediment increased progressively over time, until reaching, after $24 \mathrm{~h}$, value ranges between 78.78\% (P86 strain) and 99.60\% (P25 strain) with significant differences among all strains. The AA results are reported graphically in Figure 2 and numerically in Table S3 (Supplementary Materials). 

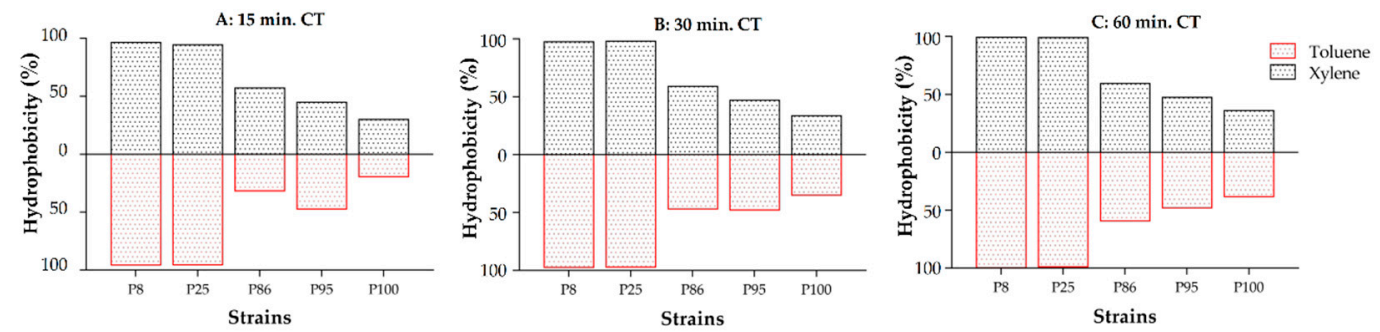

Figure 1. Adhesion of the L. plantarum five selected strains to toluene and xylene (expressed as hydrophobicity \%) measured using bacterial ability to adhere to hydrocarbons (BATH) test after different contact times (CTs). (A) $15 \mathrm{~min}$; (B): $30 \mathrm{~min}$; (C) $60 \mathrm{~min}$.

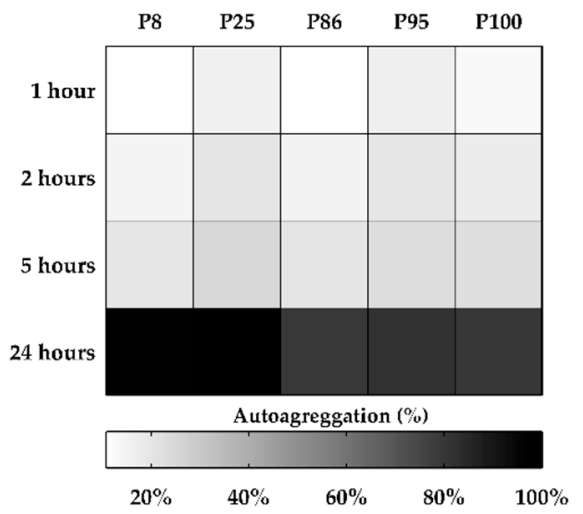

Figure 2. Auto-aggregation (AA\%) of the L. plantarum strains expressed as optical density (OD) value at $580 \mathrm{~nm}$.

\subsection{Biochemical Characterization}

The results of the enzymatic profile, obtained using an API ZYM kit, are shown in Table 2. P25 and P95 strains did not show esterase-lipase, leucine- and valine-arylamidase and $\alpha$-fucosidase activity. In addition, P8 strain did not exhibit $\alpha$-galactosidase and esterase activity, which were detected in the other strains. All the strains exhibited alkaline phosphatase, $\beta$-galactosidase, alpha- and $\beta$-glucosidase and $\mathrm{N}$-acetyl- $\beta$-glucosaminidase activity.

The carbohydrate assimilation patterns, detected using API 50 CHL medium, are shown in Table 3. All the L. plantarum five strains showed very similar profiles. Only P8 strain did not ferment the methyl-a-D-mannopyranoside. P25 and P86 strains were able to ferment l-sorbose, and P100 was able to ferment the d-xylose, unlike the other strains.

Table 2. Enzymatic profile of the five L. plantarum strains performed using API-ZYM system (BioMèrieux). + positive; - negative.

\begin{tabular}{cccccc}
\hline & \multicolumn{7}{c}{ L. plantarum Strains } \\
\cline { 2 - 5 } Enzyme Assayed & P8 & P25 & P86 & P95 & P100 \\
\hline Alkaline phosphatase & + & + & + & + & + \\
Esterase (C4) & - & + & + & + & + \\
Esterase lipase (C8) & + & - & + & - & + \\
Lipase (C14) & - & - & - & - & - \\
Leucine arylamidase & + & - & + & - & + \\
Valine arylamidase & + & - & + & - & + \\
Cystine arylamidase & - & - & - & - & - \\
\hline
\end{tabular}


Table 2. Cont.

\begin{tabular}{cccccc}
\hline Enzyme Assayed & \multicolumn{5}{c}{ L. plantarum Strains } \\
\cline { 2 - 6 } & P8 & P25 & P86 & P95 & P100 \\
\hline Trypsin & - & - & - & - & - \\
$\alpha$-chymotryspin & - & - & - & - & - \\
Acid phosphatase & - & - & - & - & - \\
Naphthol-AS-BI-phosphohydrolase & + & - & - & - & - \\
$\alpha$-galactosidase & - & + & + & + & + \\
$\beta$-galactosidase & + & + & + & + & + \\
$\beta$-glucuronidase & - & - & - & - & - \\
$\alpha$-glucosidase & + & + & + & + & + \\
$\beta$-glucosidase & + & + & + & + & + \\
$\alpha$-mannosidase & + & + & + & + & + \\
$\alpha$-fucosidase & - & - & - & - & - \\
& - & - & + & - & + \\
\hline
\end{tabular}

Table 3. Carbohydrate assimilation patterns of the five L. plantarum strains, performed using API 50 CHL system kit. + positive; - negative.

\begin{tabular}{|c|c|c|c|c|c|}
\hline \multirow{2}{*}{ Carbohydrates } & \multicolumn{5}{|c|}{ L. Plantarum Strains } \\
\hline & P8 & $\mathbf{P} 25$ & P86 & P95 & P100 \\
\hline Glycerol & - & - & - & - & - \\
\hline Erythritol & - & - & - & - & - \\
\hline D-arabinose & - & - & - & - & - \\
\hline L-arabinose & + & + & + & + & + \\
\hline D-Ribose & + & + & + & + & + \\
\hline D-Xylose & - & - & - & - & + \\
\hline L-Xylose & - & - & - & - & - \\
\hline D-adonitol & - & - & - & - & - \\
\hline Methyl-b-D-Xylopyranoside & - & - & - & - & - \\
\hline D-Galactose & + & + & + & + & + \\
\hline D-Glucose & + & + & + & + & + \\
\hline D-Fructose & + & + & + & + & + \\
\hline D-Mannose & + & + & + & + & + \\
\hline L-Sorbose & - & + & + & - & - \\
\hline L-Rhamnose & - & - & - & - & - \\
\hline Dulcitol & - & - & - & - & - \\
\hline Inositol & - & - & - & - & - \\
\hline D-Mannitol & + & + & + & + & + \\
\hline D-Sorbitol & + & + & + & + & + \\
\hline Methyl-a-D-Mannopyranoside & - & + & + & + & + \\
\hline Methyl-a-D-Glucopyranoside & - & - & - & - & - \\
\hline N-Acetyl-Glucopyranoside & + & + & + & + & + \\
\hline Amygdaline & + & + & + & + & + \\
\hline Arbutine & + & + & + & + & + \\
\hline Esculine citrate de fer & + & + & + & + & + \\
\hline Salicine & + & + & + & + & + \\
\hline D-Cellobiose & + & + & + & + & + \\
\hline D-Maltose & + & + & + & + & + \\
\hline D-Lactose & + & + & + & + & + \\
\hline D-Melibiose & + & + & + & + & + \\
\hline D-Saccharose & + & + & + & + & + \\
\hline D-Trehalose & + & + & + & + & + \\
\hline Inuline & - & - & - & - & - \\
\hline
\end{tabular}


Table 3. Cont.

\begin{tabular}{cccccc}
\hline Carbohydrates & \multicolumn{7}{c}{ L. Plantarum Strains } \\
\cline { 2 - 6 } & P8 & P25 & P86 & P95 & P100 \\
\hline D-Melezitose & + & + & + & + & + \\
D-Raffinose & + & + & + & + & + \\
Amidon & - & - & - & - & - \\
Glycogene & - & - & - & - & - \\
Xylitol & - & - & - & - & - \\
Gentiobiose & + & + & + & + & + \\
D-Turanose & + & + & + & + & + \\
D-Lyxose & - & - & - & - & - \\
D-Tagatose & - & - & - & - & - \\
D-Fucose & - & - & - & - & - \\
L-Fucose & - & - & - & - & - \\
D-Arabitol & - & - & - & - & - \\
L-Arbitol & - & - & - & - & - \\
Potassium Gluconate & - & - & - & - & - \\
potassium 2-Cetogluconate & - & - & - & - & - \\
potassium 5-Cetogluconate & - & - & - & - & - \\
\hline
\end{tabular}

\subsection{Bacterial Survival in Sugar Syrup}

The bacterial osmotic tolerance was assessed based on survival ability in two different sugar syrups and the results are showed in Table 4 . In test A ( $40 \%$ glucose $+20 \%$ fructose, $\mathrm{pH} 4.2)$, after $24 \mathrm{~h}$ of storage, the P25 strain exhibited a reduction in cell viable density of about 2 log units, the other strains maintained a high cell density around $7.0 \log \mathrm{CFU} / \mathrm{mL}$; after $48 \mathrm{~h}$ of storage, the five strains maintained a cell density ranging between 3.22 (P25 strain) and 5.84 (P95 strain) log CFU/mL. In test B, using sugar syrup with $50 \%$ of sucrose at $\mathrm{pH} 4.2$, after $24 \mathrm{~h}$ of storage, the viable cell density of the $\mathrm{P} 8$, P86, P95 and P100 strains remained similar to the initial one and decreased, by about 1 log unit, after $48 \mathrm{~h}$. For the P25 strain, $1 \log$ reduction, after $24 \mathrm{~h}$, and $2 \log$ reduction, after $48 \mathrm{~h}$, of initial viability were detected.

Table 4. Survival of the L. plantarum strains in sugar syrups stored for $24-48 \mathrm{~h}$ at $20{ }^{\circ} \mathrm{C}$. Test A: $40 \%$ glucose $+20 \%$ fructose, $\mathrm{pH} 4.2$; test $\mathrm{B}: 50 \%$ sucrose, $\mathrm{pH}$ 4.2. Results are shown as mean \pm standard deviation $(n=3)$. For every sugar syrup, different uppercase letters $(A-C)$, in each column, and different lowercase letters $(\mathrm{a}-\mathrm{d})$, in each row, indicate significant differences $(p<0.05)$.

\begin{tabular}{ccccccc}
\hline \multirow{2}{*}{$\begin{array}{c}\text { Storage } \\
\text { Time (h) }\end{array}$} & \multirow{2}{*}{$\begin{array}{c}\text { Sugar Syrup } \\
\text { Composition }\end{array}$} & \multicolumn{5}{c}{ Survival (log CFU/mL) of L. Plantarum Strains } \\
\cline { 3 - 7 } & & $\mathbf{P 8}$ & $\mathbf{P 2 5}$ & $\mathbf{P 8 6}$ & P95 & P100 \\
\hline $\mathrm{T}_{0}$ & $\mathrm{~A}$ & $7.30 \pm 0.06^{\mathrm{Ba}}$ & $7.29 \pm 0.03^{\mathrm{Aa}}$ & $7.32 \pm 0.04^{\mathrm{Ca}}$ & $7.34 \pm 0.03^{\mathrm{Ca}}$ & $7.30 \pm 0.04^{\mathrm{Ca}}$ \\
$\mathrm{T}_{24}$ & $40 \%$ glucose & $7.23 \pm 0.02^{\mathrm{Bb}}$ & $5.01 \pm 0.04^{\mathrm{Ab}}$ & $7.11 \pm 0.02^{\mathrm{Bb}}$ & $7.19 \pm 0.04^{\mathrm{Bb}}$ & $7.20 \pm 0.05^{\mathrm{Bb}}$ \\
$\mathrm{T}_{48}$ & $20 \%$ fructose & $4.28 \pm 0.04^{\mathrm{Ab}}$ & $3.22 \pm 0.02^{\mathrm{Aa}}$ & $5.73 \pm 0.05^{\mathrm{Ad}}$ & $5.84 \pm 0.03^{\mathrm{Ae}}$ & $5.14 \pm 0.02^{\mathrm{Ac}}$ \\
\hline $\mathrm{T}_{0}$ & \multirow{3}{*}{$\mathrm{B}$} & $7.23 \pm 0.06^{\mathrm{Ba}}$ & $7.15 \pm 0.04^{\mathrm{Ca}}$ & $7.22 \pm 0.04^{\mathrm{Ba}}$ & $7.20 \pm 0.02^{\mathrm{Ba}}$ & $7.29 \pm 0.02^{\mathrm{Ca}}$ \\
$\mathrm{T}_{24}$ & $50 \%$ sucrose & $7.21 \pm 0.05^{\mathrm{Bc}}$ & $6.06 \pm 0.05^{\mathrm{Ba}}$ & $7.17 \pm 0.03^{\mathrm{Bc}}$ & $7.16 \pm 0.02^{\mathrm{Bc}}$ & $7.06 \pm 0.06^{\mathrm{Bb}}$ \\
$\mathrm{T}_{48}$ & & $6.14 \pm 0.02^{\mathrm{Ab}}$ & $5.15 \pm 0.02^{\mathrm{Aa}}$ & $6.50 \pm 0.05^{\mathrm{Ad}}$ & $6.35 \pm 0.04^{\mathrm{Ac}}$ & $6.54 \pm 0.04^{\mathrm{Ad}}$ \\
\hline
\end{tabular}

\section{Discussion}

The role that probiotic bacteria can play as antagonists of honeybee pathogens, using the honeybee digestive tract as the site of infection, is very important $[23,33,42,43]$. The LAB antimicrobial action is often due to different factors: nutritional competition and compounds production as organic acids, fatty acids, proteinaceous compounds, phenolic acids and hydrogen peroxide $[80,81]$. In the inhibition test, carried out using the agar well diffusion method, the BC of the L. plantarum five strains showed a greater antimicrobial activity against $P$. larvae ATCC 9545, compared to that showed by CFS. Our results suggest that Lactiplantibacilli antagonistic action is due to different compounds 
present in BC that could increase overall antimicrobial activity. The absence of inhibition in the control test, carried out with MRS acidified, excludes that the inhibitive action of bacterial cultures is due to a low $\mathrm{pH}$. In addition, the inability of many L. plantarum strains to inhibit P. larvae ATCC 9545 (Table S1) suggests that the antimicrobial activity is not due to nutritional competition. In this regard, previous research demonstrated that some LABs produce extracellular substances, secreted or tied to the cell wall, which can perform an inhibitory action against competing microorganisms $[43,82,83]$. Some extracellular polymeric substances (polysaccharides, proteins, nucleic acids and lipids) are responsible for the cohesion of microorganisms and involved in biofilm formation [84]. The EPS production and the biofilm formation by LAB could be an effective strategy against biofilms and colonization of pathogenic bacteria, since they compete with them for nutrients and space with different mechanisms of action [85-92]. Fünfhaus et al. [93] showed that P. larvae were able to form biofilms at the beginning of the saprophytic phase, and this could promote optimal colonization of the honeybee larvae cadaver and the access to all nutrients. Several studies reported that some L. plantarum strains produce exopolysaccharides that, as well as contributing to biofilm formation, can exert an antimicrobial action [89,94-96]. Based on these considerations, we evaluated the ability of selected L. plantarum strains to produce extracellular polysaccharides (EPS). Our results showed that in MRS broth at $37^{\circ} \mathrm{C}$, and aerobiosis conditions, all the L. plantarum tested produced EPS and, in accordance with other researchers, this ability can be highly variable among L. plantarum strains [97]. Furthermore, the strains producing greater amounts of EPS also caused the strongest inhibitory action against P. larvae (Table 1). This suggests that there may be a correlation between these two properties. Further studies are needed to investigate EPS composition and to assess its capacity to inhibit spore germination, biofilm formation and vegetative growth of P. larvae. In addition to EPS production, also surface hydrophobicity and auto-aggregation are phenotypic traits that favor the biofilm formation and stability of microbial strains in the gastrointestinal tract $[98,99]$. The adhesion to intestinal epithelial cells is an important prerequisite for colonization of probiotic bacteria, preventing their immediate elimination by peristalsis and providing a competitive advantage in this ecosystem. In our work, we tested the selected strains potentiality to adhere to the intestinal tract, using bacterial adhesion to hydrocarbons (BATH), a method that determines the hydrophobicity or hydrophilic nature of the cell surface $[100,101]$. The hydrophobicity was assessed by carefully mixing a bacterial culture and hydrocarbon suspension (xylene and toluene) and then the decrease in optical density of the culture phase was evaluated. Based on the adherence \% to hydrocarbons, the LAB could be classified into three groups: those with low (0 to 35\%), moderate (36 to 70\%) and high hydrophobicity (71 to $100 \%$ ) [102,103]. Under these ranges, in the BATH test, P86, P95 and P100 L. plantarum strains showed a moderate hydrophobicity, on the contrary, P8 and P25 showed a high one. The variable values indicate that hydrophobicity appears to be strain-dependent and not species-dependent. In the future, it would be necessary to perform the assay with cell lines to confirm the ability of the selected strains to adhere to epithelial cells. In the environment, microorganisms live as planktonic cells and prefer growing as aggregates. This self-binding is termed auto-aggregation or auto-agglutination. The ability to auto-aggregate (form floccules) of probiotic bacteria is a correlate with adhesion, is a prerequisite for colonization and protection of the gastrointestinal tract and appears to be the first step in the formation of biofilms [104-106]. In general, our results highlighted that the five L. plantarum strains tested showed a high auto-aggregation ability and that the percentage of aggregated cells increased over time, in accordance with previous results obtained by other researchers, who have conducted similar studies on strains belonging to the same species [107]. Except for the P8 and P25 strains, which showed a similar aggregation capacity, significant differences $(p<0.05)$ were observed among the strains. This confirms that also the AA is a strain-dependent, not species-dependent, phenotypic character $[99,108]$. In recent years, beekeeping has become a fundamental need to intervene with an additional carbohydrate supplement for bees to integrate insufficient stocks, for spring and autumn stimulation of colonies or to completely replace stocks. The most widely used syrups contain sucrose, glucose and fructose $[109,110]$. The viability of probiotic organisms is a very important aspect; before 
resisting the gastrointestinal tract, they must be able to survive during manufacturing and storage of probiotic products in order to express health benefits for the host. In our experimental studies we evaluated the capacity of five L. plantarum selected strains to tolerate a high concentration of sucrose $(50 \%)$ and of glucose and fructose mixture $(40+20 \%)$ at $\mathrm{pH} 4.2$. Honeybees are attracted by high concentrations of sugar syrup, and this behavior becomes important to find a compromise between maximum attractiveness for honeybees and the survival of LAB. The results showed a good osmotic tolerance of all strains in all combinations. This property would ensure a high vitality if bacteria were added in sugar syrups, used as additional food in hives. Metabolic activities of the microbiota are key for symbiotic interactions in the honeybee gut and they have an impact on the health and disease of the host in different ways [111]. Gut microbiota participate in various processes, including defense systems and protection from pathogens, detoxification from harmful molecules, supply of essential nutrients and food digestion [112-115]. A balanced gut microbiota is necessarily associated with bee health since it provides countless enzymatic activities to break down the complex sugars of the honeybee's diet $[29,113,116]$. The enzyme profile, which we studied, showed that the five L. plantarum selected strains possess alpha- and beta-glycosidase activities. The beta-glycosidase is capable of hydrolyzing the glycosylated aromatic precursors, releasing odorous compounds including monoterpenes and increasing the bioavailability of antioxidative plant metabolites in honey, beebread and royal jelly $[59,61,117-125]$. In addition, beta-glycosidase is important, because in combination with other enzymes, including cellulase and hemicellulase, it contributes to the hydrolysis of cellulose [126]. Alpha-glycosidase enzyme converts maltose to glucose and is also directly involved, together with alpha-amylase, in the degradation of starch granules [127]. The impact of carbohydrates on bee survival has been studied, and it is well established that bees live longest on syrup containing sucrose, glucose or fructose [128]. Honeybees collect carbohydrate-rich food to support their colonies, and yet, certain carbohydrates present in their diet have been described as toxic because these insects lack the appropriate enzymes for their digestion [129]. These carbohydrates include the monosaccharides mannose, galactose, xylose, arabinose and rhamnose and the oligosaccharides lactose, melibiose, raffinose and melezitose [130-134]. They are contained in natural nectar or derived from pectin hydrolysis or synthesized as melezitose. This sugar, composed of glucose and turanose and produced by aphids, is primary trisaccharide in honeydew, where it can constitute up to 70\% of the sugar fraction $[135,136]$. The results of carbohydrate assimilation tests showed that the P8, P25, P86, P95 and P100 L. plantarum strains are able to metabolize arabinose, galactose, lactose, mannose, melibiose, melezitose and raffinose, considered potentially toxic to honeybees. Given their ability to simultaneously participate in the breakdown of complex polysaccharides and metabolize toxic sugars, the role of these L. plantarum strains in improving dietary tolerance as well as maintaining the health of their hosts might be notable $[131,137,138]$. The selection and availability of new selected bacteria with good functional characters and with antagonistic activity against $P$. larvae always opens up interesting perspectives for new biocontrol strategies of diseases such as the AFB. Some researchers have highlighted the effectiveness of LAB in controlling this disease $[45-47,76-78,139,140]$, and other researches have shown that effectiveness is not always certain in the hive [141,142] or that supplementation of honeybee diet, with improper probiotics, can be harmful to honeybees $[143,144]$. The functional properties, shown in vitro using L. plantarum strains, do not result axiomatically in health benefits for honeybee colonies. It is therefore necessary to assess in the future, in vivo/in situ, the role that these bacteria can have in maintaining the well-being of bees, and in particular, it is necessary to assess the contribution they can make in a prophylactic strategy against AFB disease.

\section{Materials and Methods}

\subsection{Microbial Cultures}

For this study sixty-one L. plantarum strains, isolated from bee bread and honeybee gut of Apis mellifera L., were used (Table S1, Supplementary Materials) [79]. These bacteria belong to the Di.A.A.A 
(Department of Agricultural, Environmental and Food Sciences) collection of the University of Molise. In antimicrobial tests, P. larvae ATCC 9545 strain was used as indicator.

\subsection{Screening of Antibacterial Activity}

Sixty-one L. plantarum strain antimicrobial activity against P. larvae ATCC 9545 was investigated, using agar spot tests. The experiments were conducted by spotting $10 \mu \mathrm{L}$ of $16 \mathrm{~h}$ LAB cultures $\left(10^{8}\right.$ $\mathrm{UFC} / \mathrm{mL}$ ) onto the surface of MRS (Oxoid Ltd., Hampshire, UK) agar plates, which were then incubated anaerobically at $37^{\circ} \mathrm{C}$ for $24 \mathrm{~h}$, to allow colonies to develop. P. larvae was cultured in $10 \mathrm{~mL}$ of brain heart infusion (BHI-Oxoid Ltd., Hampshire, UK) at $37^{\circ} \mathrm{C}$ for $16 \mathrm{~h}$. Subsequently, $100 \mu \mathrm{L}$ of overnight culture $\left(10^{7} \mathrm{UFC} / \mathrm{mL}\right)$ were inoculated into $7 \mathrm{~mL}$ of BHI soft agar $\left(0.7 \%\right.$ agar) maintained at $45^{\circ} \mathrm{C}$ and poured over the MRS plates on which the selected L. plantarum were grown. The plates were incubated aerobically at $37^{\circ} \mathrm{C}$. The tests were conducted in triplicate, and after $48 \mathrm{~h}$, the inhibition was evaluated by measuring the width $(\mathrm{mm})$ of the clear zone (ZOI) around the colonies of the L. plantarum strains.

\subsection{Determination of Antibacterial Activity}

The L. plantarum strains producing a ZOI greater than $4 \mathrm{~mm}$, in the agar spot test, were selected, and their antimicrobial activity against $P$. larvae ATCC 9545 was tested using agar well diffusion assay. The L. plantarum strains were grown in MRS broth and, after $16 \mathrm{~h}$ at $37^{\circ} \mathrm{C}$, the cultural broth (BC) of every single strain was centrifugated ( $8000 \mathrm{rpm}$ for $20 \mathrm{~min}$ at $4{ }^{\circ} \mathrm{C}$ ) and the supernatant (CFS) was sterilized by filtration (cellulose acetate membrane, pore size $0.22 \mu \mathrm{m}$, Sigma-Aldrich; St. Louis, Missouri, USA). The antimicrobial activity of the selected strains was evaluated according to Tremonte et al. protocol [65]. Briefly, $20 \mathrm{~mL}$ of BHI soft agar (0.7\% agar) inoculated with an overnight culture of $P$. larvae (final concentration of about $10^{7} \mathrm{CFU} / \mathrm{mL}$ ) were poured into Petri plates. Wells of $5.0 \mathrm{~mm}$ in diameter were bored into a single plate and $50 \mu \mathrm{L}$ of BC and of CFS, of each producer strain, were placed into different wells. As control, $50 \mu \mathrm{L}$ of MRS, adjusted to $\mathrm{pH} 3.5$ with hydrochloric acid $1 \mathrm{~N}$ (Sigma-Aldrich), were used. After incubation at $37^{\circ} \mathrm{C}$ for $48 \mathrm{~h}$, the plates were observed and antibacterial activity was reported as width $(\mathrm{mm})$ of clear zone of inhibition (ZOI) around the inoculated wells $[19,81]$. The tests were conducted in triplicate.

\subsection{Biochemical Characterization}

L. plantarum strains have been assessed for their carbohydrate fermentation pattern, using an API 50CHL system kit, and for enzymatic patterns, using an API ZYM system kit, according to the manufacturer's instructions (bioMérieux SA, Marcy l'Etoile, France).

\subsection{Auto-Aggregation}

The auto-aggregation assay was performed according to Cozzolino et al. [145]. Briefly, the Lactobacilli cultures were collected using centrifugation (8000 rpm for $10 \mathrm{~min}$ at $4{ }^{\circ} \mathrm{C}$ ) during the logarithmic growth phase. Subsequently, the cells were washed three times with phosphate saline buffer (PBS, Sigma-Aldrich). Further, they were washed twice and re-suspended in PBS to an optical density $(\mathrm{OD})$ of approx. $0.5\left(\mathrm{~A}_{580}\right)$, in order to standardize the bacterial concentration at $10^{8}$ $\mathrm{CFU} / \mathrm{mL}$. The tests were conducted in triplicate and the cell auto-aggregation was measured at 1,2, 5 and $24 \mathrm{~h}$ of incubation at $37^{\circ} \mathrm{C}$, after which the $\mathrm{OD}$ at $580 \mathrm{~nm}$ of the upper suspension was measured using a spectrophotometer (Multilabel Counter-PerkinElmer 1420, San Jose, USA). The percentage of auto-aggregation was calculated using the following formula: Auto-aggregation $\%(A)=\left(1-\mathrm{OD}_{\mathrm{t}} / \mathrm{OD}_{0}\right)$ $\times 100$, where $\mathrm{OD}_{0}$ is the absorbance at time 0 , and $\mathrm{OD}_{\mathrm{t}}$ is the absorbance detected after $1,2,5$, and $24 \mathrm{~h}$.

\subsection{Cell Surface Hydrophobicity}

The determination of cell surface hydrophobicity, based on the bacterial ability to adhere to hydrocarbons (BATH), was evaluated on L. plantarum strains, using xylene and toluene 
(Sigma-Aldrich) [145]. Hydrophobicity was calculated as the percentage decrease in OD of the initial bacterial suspension and was expressed using the following formula: \% Hydrophobicity $=\left(\mathrm{OD}_{0}\right.$ $\left.-\mathrm{OD}_{\mathrm{t}} / \mathrm{OD}_{0}\right) \times 100$, where $\mathrm{OD}_{\mathrm{t}}$ represents the absorbance value after extraction with hydrocarbons $(15,30$ and $60 \mathrm{~min})$, and $\mathrm{OD}_{0}$ represents the absorbance value before extraction with hydrocarbons. The tests were conducted in triplicate.

\subsection{Exopolysaccharides Production (EPS)}

For exopolysaccharide production, $100 \mathrm{~mL}$ of MRS was inoculated with a $1 \%(v / v)$ of overnight pre-culture. After incubation, at $37^{\circ} \mathrm{C}$ for $48 \mathrm{~h}$, cells were separated using centrifugation at $7000 \mathrm{rpm}$ for $30 \mathrm{~min}$ at $4{ }^{\circ} \mathrm{C}$. Trichloroacetic acid was added to the supernatant, to a final concentration of $7 \%$ $(w / v)$, which was then incubated at $4{ }^{\circ} \mathrm{C}$ for $12 \mathrm{~h}$. The precipitated proteins were removed using centrifugation at $12,000 \mathrm{rpm}$ for $30 \mathrm{~min}$ at $4{ }^{\circ} \mathrm{C}$. The supernatant was then mixed with three volumes of pre-chilled ethanol (95\%), vigorously stirred and kept at $4{ }^{\circ} \mathrm{C}$ overnight. EPS sediments were collected using centrifugation at $17,000 \mathrm{rpm}$ for $30 \mathrm{~min}$ at $4{ }^{\circ} \mathrm{C}$. As control, $100 \mathrm{~mL}$ of MRS broth without bacterial inoculum were used. The final polysaccharide fractions were lyophilized and their amount was determined by measuring the weight. The net quantity was obtained by subtracting the amount of EPS obtained from non-inoculated MRS broth. The tests were conducted in triplicate. All the chemical compounds used were supplied by Sigma-Aldrich.

\subsection{Bacterial Survival in Sugar Syrup}

To assess osmotic tolerance, a test was performed according to Iorizzo et al. [44], with some modifications. L. plantarum strains were grown in MRS broth at $37^{\circ} \mathrm{C}$ and after $24 \mathrm{~h}$ the cells were harvested using centrifugation at $8000 \mathrm{rpm}$ for $10 \mathrm{~min}$ at $4{ }^{\circ} \mathrm{C}$. The fresh pellets were washed twice with PBS buffer and were inoculated in sugar syrup in order to obtain an initial concentration of $10^{7}$ $\mathrm{CFU} / \mathrm{mL}$. The experimental conditions were the following; test A: sugar syrup constituted by $40 \%$ glucose $+20 \%$ fructose $(w / v)$ in distilled water at $\mathrm{pH} 4.2$; test B: sugar syrup constituted by $50 \%(w / v)$ sucrose in distilled water at $\mathrm{pH}$ 4.2. The sugar syrup was acidified using $\mathrm{HCl} 1 \mathrm{~N}$ and sterilized using filtration (cellulose acetate membrane, pore size $0.22 \mu \mathrm{m}$, Sigma-Aldrich). The experiments, conducted in triplicate, were performed at $20^{\circ} \mathrm{C}$ and the bacterial viability was determined after 0,24 and $48 \mathrm{~h}$ by plating in MRS agar $\left(37^{\circ} \mathrm{C}\right.$ for $72 \mathrm{~h}$ in anaerobic condition).

\subsection{Statistical Analysis}

All data, obtained by three independent experiments, were expressed as mean \pm standard deviation (SD). Statistical analysis was performed through the analysis of variance (ANOVA) followed by the Tuckey's multiple comparison. Statistical significance was attributed to $p$-values $<0.05$. The software SPSS (IBM SPSS Statistics 21) was used for the analysis.

\section{Conclusions}

The results of our research have shown that P8, P25, P86, P95 and P100 L. plantarum strains are able to inhibit P. larvae ATCC 9545 and they own some physiological and functional properties that make these strains candidate as a probiotic for the honeybee. However, we may consider the preliminary and preparatory results for future studies that can consolidate the acquired knowledge and assess the benefits these bacteria may have on honeybee health in the hive. In addition, it will be important to investigate the factors that determine antimicrobial action and to evaluate antagonist activity of $L$. plantarum strains in vivo/in situ.

Supplementary Materials: The following are available online at http://www.mdpi.com/2079-6382/9/8/442/s1. Table S1: L. plantarum strains collection; Table S2: Hydrophobicity (\%); Table S3: Auto-aggregation (\%).

Author Contributions: Conceptualization, M.I. (Massimo Iorizzo), R.C.; data curation, M.S., P.T. and E.S.; formal analysis, M.I. (Mario Ianiro), B.T., S.J.L., S.G., S.P., F.V. and A.C.; funding acquisition, M.M. and A.D.C.; investigation, 
B.T., S.P. and P.T.; methodology, S.J.L., S.G., B.T., F.V. and A.C.; project administration, S.P. and M.M.; resources, R.C. and A.D.C.; software, F.L. and M.M.; supervision, R.C. and A.D.C.; validation, M.S.; writing-original draft, M.I. (Massimo Iorizzo) and B.T.; writing-review and editing, M.I. (Massimo Iorizzo), S.G. and F.L. All authors have read and agreed to the published version of the manuscript.

Funding: This research was carried out as part of the project "BEEOBSERVER" financed by the Department of Agriculture, Environmental and Food Sciences, University of Molise, CB, Italy. ID: H32F16000610005.

Conflicts of Interest: The authors declare that they have no conflicts of interest.

\section{References}

1. Hansen, H.; Brødsgaard, C.J. American foulbrood: A review of its biology, diagnosis and control. Bee World 1999, 80, 5-23. [CrossRef]

2. Ebeling, J.; Knispel, H.; Hertlein, G.; Fünfhaus, A.; Genersch, E. Biology of Paenibacillus larvae, a deadly pathogen of honey bee larvae. Appl. Microbiol. Biotechnol. 2016, 100, 7387-7395. [CrossRef]

3. Stephan, J.G.; de Miranda, J.R.; Forsgren, E. American foulbrood in a honeybee colony: Spore-symptom relationship and feedbacks between disease and colony development. BMC Ecol. 2020, 20. [CrossRef]

4. Genersch, E.; Evans, J.D.; Fries, I. Honey bee disease overview. J. Invertebr. Pathol. 2010, 103, S2-S4. [CrossRef]

5. Williams, D.L. A Veterinary Approach to the European Honey Bee (Apis mellifera). Vet. J. 2000, 160, 61-73. [CrossRef]

6. Elzen, P.J.; Westervelt, D.; Causey, D.; Ellis, J.; Hepburn, H.R.; Neumann, P. Method of Application of Tylosin, an Antibiotic for American Foulbrood Control, with Effects on Small Hive Beetle (Coleoptera: Nitidulidae) Populations. J. Econ. Entomol. 2002, 95, 1119-1122. [CrossRef]

7. Kochansky, J. Screening alternative antibiotics against oxytetracycline-susceptible and -resistant Paenibacillus larvae. Apidologie 2001, 32. [CrossRef]

8. Spivak, M.; Reuter, G.S. Resistance to American foulbrood disease by honey bee colonies Apis mellifera bred for hygienic behavior. Apidologie 2001, 32, 555-565. [CrossRef]

9. Beims, H.; Wittmann, J.; Bunk, B.; Spröer, C.; Rohde, C.; Günther, G.; Rohde, M.; von der Ohe, W.; Steinert, M. Paenibacillus larvae-Directed Bacteriophage HB10c2 and Its Application in American Foulbrood-Affected Honey Bee Larvae. Appl. Environ. Microbiol. 2015, 81, 5411-5419. [CrossRef]

10. Alvarado, I.; Margotta, J.W.; Aoki, M.M.; Flores, F.; Agudelo, F.; Michel, G.; Elekonich, M.M.; Abel-Santos, E. Inhibitory effect of indole analogs against Paenibacillus larvae, the causal agent of American foulbrood disease. J. Insect Sci. Online 2017, 17. [CrossRef]

11. Evans, J.D. Diverse origins of tetracycline resistance in the honey bee bacterial pathogen Paenibacillus larvae. J. Invertebr. Pathol. 2003, 83, 46-50. [CrossRef]

12. Miyagi, T.; Peng, C.Y.S.; Chuang, R.Y.; Mussen, E.C.; Spivak, M.S.; Doi, R.H. Verification of Oxytetracycline-Resistant American Foulbrood Pathogen Paenibacillus larvae in the United States. J. Invertebr. Pathol. 2000, 75, 95-96. [CrossRef] [PubMed]

13. Raymann, K.; Shaffer, Z.; Moran, N.A. Antibiotic exposure perturbs the gut microbiota and elevates mortality in honeybees. PLoS Biol. 2017, 15, e2001861. [CrossRef]

14. Bargańska, Ż.; Namieśnik, J.; Ślebioda, M. Determination of antibiotic residues in honey. Biog. Volatile Org. Compd. SI 2011, 30, 1035-1041. [CrossRef]

15. Alonso-Salces, R.M.; Cugnata, N.M.; Guaspari, E.; Pellegrini, M.C.; Aubone, I.; De Piano, F.G.; Antunez, K.; Fuselli, S.R. Natural strategies for the control of Paenibacillus larvae, the causative agent of American foulbrood in honey bees: A review. Apidologie 2017, 48, 387-400. [CrossRef]

16. Grady, E.N.; MacDonald, J.; Liu, L.; Richman, A.; Yuan, Z.-C. Current knowledge and perspectives of Paenibacillus: A review. Microb. Cell Factories 2016, 15. [CrossRef]

17. Chaimanee, V.; Thongtue, U.; Sornmai, N.; Songsri, S.; Pettis, J.S. Antimicrobial activity of plant extracts against the honeybee pathogens, Paenibacillus larvae and Ascosphaera apis and their topical toxicity to Apis mellifera adults. J. Appl. Microbiol. 2017, 123, 1160-1167. [CrossRef]

18. Flesar, J.; Havlik, J.; Kloucek, P.; Rada, V.; Titera, D.; Bednar, M.; Stropnicky, M.; Kokoska, L. In vitro growth-inhibitory effect of plant-derived extracts and compounds against Paenibacillus larvae and their acute oral toxicity to adult honey bees. Vet. Microbiol. 2010, 145, 129-133. [CrossRef] 
19. Testa, B.; Lombardi, S.J.; Macciola, E.; Succi, M.; Tremonte, P.; Iorizzo, M. Efficacy of olive leaf extract (Olea europaea L. cv Gentile di Larino) in marinated anchovies (Engraulis encrasicolus, L.) process. Heliyon 2019, 5 , e01727. [CrossRef]

20. Daglia, M. Polyphenols as antimicrobial agents. Food Biotechnol. Plant Biotechnol. 2012, 23, 174-181. [CrossRef]

21. Solórzano-Santos, F.; Miranda-Novales, M.G. Essential oils from aromatic herbs as antimicrobial agents. Food Biotechnol. Plant Biotechnol. 2012, 23, 136-141. [CrossRef] [PubMed]

22. Selma, M.V.; Espín, J.C.; Tomás-Barberán, F.A. Interaction between Phenolics and Gut Microbiota: Role in Human Health. J. Agric. Food Chem. 2009, 57, 6485-6501. [CrossRef] [PubMed]

23. Alberoni, D.; Gaggìa, F.; Baffoni, L.; Di Gioia, D. Beneficial microorganisms for honey bees: Problems and progresses. Appl. Microbiol. Biotechnol. 2016, 100, 9469-9482. [CrossRef] [PubMed]

24. Crotti, E.; Balloi, A.; Hamdi, C.; Sansonno, L.; Marzorati, M.; Gonella, E.; Favia, G.; Cherif, A.; Bandi, C.; Alma, A.; et al. Microbial symbionts: A resource for the management of insect-related problems. Microb. Biotechnol. 2012, 5, 307-317. [CrossRef]

25. Raymann, K.; Moran, N.A. The role of the gut microbiome in health and disease of adult honey bee workers. Curr. Opin. Insect Sci. 2018, 26, 97-104. [CrossRef]

26. Wu, M.; Sugimura, Y.; Taylor, D.; Yoshiyama, M. Honeybee Gastrointestinal Bacteria for Novel and Sustainable Disease Control Strategies. J. Dev. Sustain. Agric. 2013, 8, 85-90. [CrossRef]

27. Fowler, A.E.; Irwin, R.E.; Adler, L.S. Parasite defense mechanisms in bees: Behavior, immunity, antimicrobials, and symbionts. Emerg. Top. Life Sci. 2019. [CrossRef]

28. Cox-Foster, D.L.; Conlan, S.; Holmes, E.C.; Palacios, G.; Evans, J.D.; Moran, N.A.; Quan, P.-L.; Briese, T.; Hornig, M.; Geiser, D.M.; et al. A Metagenomic Survey of Microbes in Honey Bee Colony Collapse Disorder. Science 2007. [CrossRef]

29. Hamdi, C.; Balloi, A.; Essanaa, J.; Crotti, E.; Gonella, E.; Raddadi, N.; Ricci, I.; Boudabous, A.; Borin, S.; Manino, A.; et al. Gut microbiome dysbiosis and honeybee health. J. Appl. Entomol. 2011, 135, 524-533. [CrossRef]

30. Schwarz, R.S.; Moran, N.A.; Evans, J.D. Early gut colonizers shape parasite susceptibility and microbiota composition in honey bee workers. Proc. Natl. Acad. Sci. USA 2016, 113, 9345. [CrossRef]

31. Genersch, E. Honey bee pathology: Current threats to honey bees and beekeeping. Appl. Microbiol. Biotechnol. 2010, 87, 87-97. [CrossRef]

32. Kwong, W.K.; Moran, N.A. Gut microbial communities of social bees. Nat. Rev. Microbiol. 2016, 14, 374-384. [CrossRef] [PubMed]

33. Vásquez, A.; Forsgren, E.; Fries, I.; Paxton, R.J.; Flaberg, E.; Szekely, L.; Olofsson, T.C. Correction: Symbionts as Major Modulators of Insect Health: Lactic Acid Bacteria and Honeybees. PLoS ONE 2012, 7. [CrossRef]

34. Endo, A.; Salminen, S. Honeybees and beehives are rich sources for fructophilic lactic acid bacteria. Syst. Appl. Microbiol. 2013, 36, 444-448. [CrossRef] [PubMed]

35. Filannino, P.; Di Cagno, R.; Tlais, A.Z.A.; Cantatore, V.; Gobbetti, M. Fructose-rich niches traced the evolution of lactic acid bacteria toward fructophilic species. Crit. Rev. Microbiol. 2019, 45, 65-81. [CrossRef] [PubMed]

36. Royan, M. Mechanisms of Probiotic Action in the Honeybee. Crit. Rev. Eukaryot. Gene Expr. 2019, $29,95-103$. [CrossRef]

37. Ramos, O.Y.; Basualdo, M.; Libonatti, C.; Vega, M.F. Current status and application of lactic acid bacteria in animal production systems with a focus on bacteria from honey bee colonies. J. Appl. Microbiol. 2020, 128, 1248-1260. [CrossRef]

38. Evans, J.D.; Lopez, D.L. Bacterial Probiotics Induce an Immune Response in the Honey Bee (Hymenoptera: Apidae). J. Econ. Entomol. 2004, 97, 752-756. [CrossRef]

39. Evans, J.D.; Aronstein, K.; Chen, Y.P.; Hetru, C.; Imler, J.-L.; Jiang, H.; Kanost, M.; Thompson, G.J.; Zou, Z.; Hultmark, D. Immune pathways and defence mechanisms in honey bees Apis mellifera. Insect Mol. Biol. 2006, 15, 645-656. [CrossRef]

40. Kwong, W.K.; Mancenido, A.L.; Moran, N.A. Immune system stimulation by the native gut microbiota of honey bees. R. Soc. Open Sci. 2017, 4. [CrossRef]

41. Janashia, I.; Choiset, Y.; Rabesona, H.; Hwanhlem, N.; Bakuradze, N.; Chanishvili, N.; Haertlé, T. Protection of honeybee Apis mellifera by its endogenous and exogenous lactic flora against bacterial infections. Ann. Agrar. Sci. 2016, 14, 177-181. [CrossRef] 
42. Rokop, Z.P.; Horton, M.A.; Newton, I.L.G. Interactions between Cooccurring Lactic Acid Bacteria in Honey Bee Hives. Appl. Environ. Microbiol. 2015, 81, 7261. [CrossRef] [PubMed]

43. Olofsson, T.C.; Butler, È.; Markowicz, P.; Lindholm, C.; Larsson, L.; Vásquez, A. Lactic acid bacterial symbionts in honeybees-An unknown key to honey's antimicrobial and therapeutic activities. Int. Wound J. 2016, 13, 668-679. [CrossRef] [PubMed]

44. Iorizzo, M.; Lombardi, S.J.; Ganassi, S.; Testa, B.; Ianiro, M.; Letizia, F.; Succi, M.; Tremonte, P.; Vergalito, F.; Cozzolino, A.; et al. Antagonistic Activity against Ascosphaera apis and Functional Properties of Lactobacillus kunkeei Strains. Antibiotics 2020, 9, 262. [CrossRef] [PubMed]

45. Arredondo, D.; Castelli, L.; Porrini, M.P.; Garrido, P.M.; Eguaras, M.J.; Zunino, P.; Antúnez, K. Lactobacillus kunkeei strains decreased the infection by honey bee pathogens Paenibacillus larvae and Nosema ceranae. Benef. Microbes 2018, 9, 279-290. [CrossRef]

46. Al-Ghamdi, A.; Ali Khan, K.; Javed Ansari, M.; Almasaudi, S.B.; Al-Kahtani, S. Effect of gut bacterial isolates from Apis mellifera jemenitica on Paenibacillus larvae infected bee larvae. Saudi J. Biol. Sci. 2018, 25, 383-387. [CrossRef]

47. Forsgren, E.; Olofsson, T.C.; Váasquez, A.; Fries, I. Novel lactic acid bacteria inhibiting Paenibacillus larvae in honey bee larvae. Apidologie 2010, 41, 99-108. [CrossRef]

48. Zheng, J.; Wittouck, S.; Salvetti, E.; Franz, C.M.A.P.; Harris, H.M.B.; Mattarelli, P.; O'Toole, P.W.; Pot, B.; Vandamme, P.; Walter, J.; et al. A taxonomic note on the genus Lactobacillus: Description of 23 novel genera, emended description of the genus Lactobacillus Beijerinck 1901, and union of Lactobacillaceae and Leuconostocaceae. Int. J. Syst. Evol. Microbiol. 2020, 70, 2782-2858. [CrossRef]

49. Mayo, B.; Flórez, A.B. Lactic Acid Bacteria: Lactobacillus spp.: Lactobacillus plantarum «. In Reference Module in Food Science; Elsevier: Amsterdam, The Netherlands, 2020; ISBN 978-0-08-100596-5.

50. Tajabadi, N.; Mardan, M.; Saari, N.; Mustafa, S.; Bahreini, R.; Manap, M.Y.A. Identification of Lactobacillus plantarum, Lactobacillus pentosus and Lactobacillus fermentum from honey stomach of honeybee. Braz. J. Microbiol. Publ. Braz. Soc. Microbiol. 2014, 44, 717-722. [CrossRef]

51. Javorský, P.; Fecskeová, L.K.; Hrehová, L.; Sabo, R.; Legáth, J.; Pristas, P. Establishment of Lactobacillus plantarum strain in honey bee digestive tract monitored using gfp fluorescence. Benef. Microbes 2017, 8, 291-297. [CrossRef]

52. Parichehreh, S.; Tahmasbi, G.; Sarafrazi, A.; Imani, S.; Tajabadi, N. Isolation and identification of Lactobacillus bacteria found in the gastrointestinal tract of the dwarf honey bee, Apis florea Fabricius, 1973 (Hymenoptera: Apidae). Apidologie 2018, 49, 430-438. [CrossRef]

53. Vásquez, A.; Olofsson, T.C. The lactic acid bacteria involved in the production of bee pollen and bee bread. J. Apic. Res. 2009, 48, 189-195. [CrossRef]

54. Kieliszek, M.; Piwowarek, K.; Kot, A.M.; Błażejak, S.; Chlebowska-Śmigiel, A.; Wolska, I. Pollen and bee bread as new health-oriented products: A review. Trends Food Sci. Technol. 2018, 71, 170-180. [CrossRef]

55. Lombardi, S.J.; Pannella, G.; Iorizzo, M.; Testa, B.; Succi, M.; Tremonte, P.; Sorrentino, E.; Di Renzo, M.; Strollo, D.; Coppola, R. Inoculum Strategies and Performances of Malolactic Starter Lactobacillus plantarum M10: Impact on Chemical and Sensorial Characteristics of Fiano Wine. Microorganisms 2020, 8, 516. [CrossRef]

56. Lombardi, S.J.; Macciola, V.; Iorizzo, M.; De Leonardis, A. Effect of different storage conditions on the shelf life of natural green table olives. Ital. J. Food Sci. 2018, 30. [CrossRef]

57. Behera, S.S.; Ray, R.C.; Zdolec, N. Lactobacillus plantarum with Functional Properties: An Approach to Increase Safety and Shelf-Life of Fermented Foods. BioMed Res. Int. 2018, 2018. [CrossRef]

58. Succi, M.; Pannella, G.; Tremonte, P.; Tipaldi, L.; Coppola, R.; Iorizzo, M.; Lombardi, S.J.; Sorrentino, E. Sub-optimal $\mathrm{pH}$ preadaptation improves the survival of Lactobacillus plantarum strains and the malic Acid consumption in wine-like medium. Front. Microbiol. 2017, 8, 470. [CrossRef]

59. De Leonardis, A.; Testa, B.; Macciola, V.; Lombardi, S.J.; Iorizzo, M. Exploring enzyme and microbial technology for the preparation of green table olives. Eur. Food Res. Technol. 2016, 242, 363-370. [CrossRef]

60. Iorizzo, M.; Testa, B.; Lombardi, S.J.; García-Ruiz, A.; Muñoz-González, C.; Bartolomé, B.; Moreno-Arribas, M.V. Silvia Jane Lombardi Selection and technological potential of Lactobacillus plantarum bacteria suitable for wine malolactic fermentation and grape aroma release. Lebensm. Wiss. Ie Technol. 2016, 73, 557-566. [CrossRef] 
61. Iorizzo, M.; Lombardi, S.J.; Macciola, V.; Testa, B.; Lustrato, G.; Lopez, F.; De Leonardis, A. Technological Potential of Lactobacillus Strains Isolated from Fermented Green Olives: In Vitro Studies with Emphasis on Oleuropein-Degrading Capability. Sci. World J. 2016, 2016. [CrossRef]

62. Liu, Q.H. The effect of fibrolytic enzyme, Lactobacillus plantarum and two food antioxidants on the fermentation quality, alpha-tocopherol and beta-carotene of high moisture napier grass silage ensiled at different temperatures. Anim. Feed Sci. Technol. 2016, 221,1-11. [CrossRef]

63. Testa, B.; Lombardi, S.J.; Tremonte, P.; Succi, M.; Tipaldi, L.; Pannella, G.; Sorrentino, E.; Iorizzo, M.; Coppola, R. Biodiversity of Lactobacillus plantarum from traditional Italian wines. World J. Microbiol. Biotechnol. 2014, 30, 2299-2305. [CrossRef] [PubMed]

64. Daranas, N.; Roselló, G.; Cabrefiga, J.; Donati, I.; Francés, J.; Badosa, E.; Spinelli, F.; Montesinos, E.; Bonaterra, A. Biological control of bacterial plant diseases with Lactobacillus plantarum strains selected for their broad-spectrum activity. Ann. Appl. Biol. 2019, 174, 92-105. [CrossRef] [PubMed]

65. Tremonte, P.; Pannella, G.; Succi, M.; Luca, T.; Sturchio, M.; Coppola, R.; Luongo, D.; Sorrentino, E. Antimicrobial activity of Lactobacillus plantarum strains isolated from different environments: A preliminary study. Int. Food Res. J. 2017, 24, 852-859.

66. Seddik, H.A.; Bendali, F.; Gancel, F.; Fliss, I.; Spano, G.; Drider, D. Lactobacillus plantarum and Its Probiotic and Food Potentialities. Probiotics Antimicrob. Proteins 2017, 9, 111-122. [CrossRef]

67. Russo, P.; Fares, C.; Longo, A.; Spano, G.; Capozzi, V. Lactobacillus plantarum with Broad Antifungal Activity as a Protective Starter Culture for Bread Production. Foods 2017, 6, 110. [CrossRef]

68. Dinev, T.; Beev, G.; Tzanova, M.; Denev, S.; Dermendzhieva, D.; Stoyanova, A. Antimicrobial activity of lactobacillus plantarum against pathogenic and food spoilage microorganisms: A review. Bulg. J. Vet. Med. 2017, 21. [CrossRef]

69. Russo, P.; Arena, M.P.; Fiocco, D.; Capozzi, V.; Drider, D.; Spano, G. Lactobacillus plantarum with broad antifungal activity: A promising approach to increase safety and shelf-life of cereal-based products. Int. J. Food Microbiol. 2017, 247, 48-54. [CrossRef]

70. Siezen, R.J.; Francke, C.; Renckens, B.; Boekhorst, J.; Wels, M.; Kleerebezem, M.; van Hijum, S.A.F.T. Complete resequencing and reannotation of the Lactobacillus plantarum WCFS1 genome. J. Bacteriol. 2012, 194, 195-196. [CrossRef]

71. Rowghani, E.; Zamiri, M.J.; Khorvash, M.; Abdollahipanah, A. The effects of Lactobacillus plantarum and Propionibacterium acidipropionici on corn silage fermentation, ruminal degradability and nutrient digestibility in sheep. Iran. J. Vet. Res. 2008, 9, 308-315. [CrossRef]

72. Abou-El-Atta, M.E.; Abdel-Tawwab, M.; Abdel-Razek, N.; Abdelhakim, T.M.N. Effects of dietary probiotic Lactobacillus plantarum and whey protein concentrate on the productive parameters, immunity response and susceptibility of Nile tilapia, Oreochromis niloticus (L.), to Aeromonas sobria infection. Aquac. Nutr. 2019, 25, 1367-1377. [CrossRef]

73. Peng, Q.; Zeng, X.F.; Zhu, J.L.; Wang, S.; Liu, X.T.; Hou, C.L.; Thacker, P.A.; Qiao, S.Y. Effects of dietary Lactobacillus plantarum B1 on growth performance, intestinal microbiota, and short chain fatty acid profiles in broiler chickens. Poult. Sci. 2016, 95, 893-900. [CrossRef] [PubMed]

74. De Vries, M.C.; Vaughan, E.E.; Kleerebezem, M.; de Vos, W.M. Lactobacillus plantarum—Survival, functional and potential probiotic properties in the human intestinal tract. 4th NIZO Dairy Conf.-Prospects Health WellSaf. 2006, 16, 1018-1028. [CrossRef]

75. Wang, J.; Ji, H.; Wang, S.; Liu, H.; Zhang, W.; Zhang, D.; Wang, Y. Probiotic Lactobacillus plantarum Promotes Intestinal Barrier Function by Strengthening the Epithelium and Modulating Gut Microbiota. Front. Microbiol. 2018, 9, 1953. [CrossRef] [PubMed]

76. Daisley, B.A.; Pitek, A.P.; Chmiel, J.A.; Al, K.F.; Chernyshova, A.M.; Faragalla, K.M.; Burton, J.P.; Thompson, G.J.; Reid, G. Novel probiotic approach to counter Paenibacillus larvae infection in honey bees. ISME J. 2020, 14, 476-491. [CrossRef] [PubMed]

77. Mudroňová, D.; Toporčák, J.; Nemcová, R.; Gancarčíková, S.; Hajdučková, V.; Rumanovská, K. Lactobacillus sp. as a potential probiotic for the prevention of Paenibacillus larvae infection in honey bees. J. Apic. Res. 2011, 50, 323-324. [CrossRef]

78. Lazzeri, A.M.; Mangia, N.P.; Mura, M.E.; Floris, I.; Satta, A.; Ruiu, L. Potential of novel food-borne Lactobacillus isolates against the honeybee pathogen Paenibacillus larvae. Biocontrol Sci. Technol. 2020, 1-12. [CrossRef] 
79. Di Donato, A. Characterization of Lactic acid bacteria isolates from Apis mellifera L. and hive product. Master's Thesis, University of Molise, Campobasso, Italy, 2016.

80. Lombardi, S.J.; De Leonardis, A.; Lustrato, G.; Testa, B.; Iorizzo, M. Yeast Autolysis in Sparkling Wine Aging: Use of Killer and Sensitive Saccharomyces cerevisiae Strains in Co-Culture. Recent Pat. Biotechnol. 2015, 9 , 223-230. [CrossRef]

81. Sorrentino, E.; Tremonte, P.; Succi, M.; Iorizzo, M.; Pannella, G.; Lombardi, S.J.; Sturchio, M.; Coppola, R. Detection of Antilisterial Activity of 3-Phenyllactic Acid Using Listeria innocua as a Model. Front. Microbiol. 2018, 9. [CrossRef]

82. Pannella, G.; Lombardi, S.J.; Coppola, F.; Vergalito, F.; Iorizzo, M.; Succi, M.; Tremonte, P.; Iannini, C.; Sorrentino, E.; Coppola, R. Effect of Biofilm Formation by Lactobacillus plantarum on the Malolactic Fermentation in Model Wine. Foods 2020, 9, 797. [CrossRef]

83. Neu, T.R.; Lawrence, J.R. Chapter 37-Extracellular polymeric substances in microbial biofilms. In Microbial Glycobiology; Holst, O., Brennan, P.J., von Itzstein, M., Moran, A.P., Eds.; Academic Press: San Diego, CA, USA, 2010; pp. 733-758. ISBN 978-0-12-374546-0.

84. Lembre, P. Exopolysaccharides of the Biofilm Matrix: A Complex Biophysical World. In The Complex World of Polysaccharides; Lorentz, C., Ed.; IntechOpen: Rijeka, Croatia, 2012; Chapter 13.

85. Berríos, P.; Fuentes, J.; Salas, D.; Carreño, A.; Aldea, P.; Fernández, F.; Trombert, A. Inhibitory effect of biofilm-forming Lactobacillus kunkeei strains against virulent Pseudomonas aeruginosa in vitro and in honeycomb moth (Galleria mellonella) infection model. Benef. Microbes 2018, 9, 257-268. [CrossRef]

86. Salas-Jara, M.J.; Ilabaca, A.; Vega, M.; García, A. Biofilm Forming Lactobacillus: New Challenges for the Development of Probiotics. Microorganisms 2016, 4, 35. [CrossRef]

87. Barzegari, A.; Kheyrolahzadeh, K.; Hosseiniyan Khatibi, S.M.; Sharifi, S.; Memar, M.Y.; Zununi Vahed, S. The Battle of Probiotics and Their Derivatives against Biofilms. Infect. Drug Resist. 2020, 13, 659-672. [CrossRef] [PubMed]

88. Patel, S.; Majumder, A.; Goyal, A. Potentials of Exopolysaccharides from Lactic Acid Bacteria. Indian J. Microbiol. 2012, 52, 3-12. [CrossRef] [PubMed]

89. Li, S.; Huang, R.; Shah, N.P.; Tao, X.; Xiong, Y.; Wei, H. Antioxidant and antibacterial activities of exopolysaccharides from Bifidobacterium bifidum WBIN03 and Lactobacillus plantarum R315. J. Dairy Sci. 2014, 97, 7334-7343. [CrossRef] [PubMed]

90. Wu, M.-H.; Pan, T.-M.; Wu, Y.-J.; Chang, S.-J.; Chang, M.-S.; Hu, C.-Y. Exopolysaccharide activities from probiotic bifidobacterium: Immunomodulatory effects (on J774A.1 macrophages) and antimicrobial properties. Int. J. Food Microbiol. 2010, 144, 104-110. [CrossRef]

91. Nehal, F.; Sahnoun, M.; Smaoui, S.; Jaouadi, B.; Bejar, S.; Mohammed, S. Characterization, high production and antimicrobial activity of exopolysaccharides from Lactococcus lactis F-mou. Microb. Pathog. 2019, 132, 10-19. [CrossRef]

92. Mahdhi, A.; Leban, N.; Chakroun, I.; Chaouch, M.A.; Hafsa, J.; Fdhila, K.; Mahdouani, K.; Majdoub, H. Extracellular polysaccharide derived from potential probiotic strain with antioxidant and antibacterial activities as a prebiotic agent to control pathogenic bacterial biofilm formation. Microb. Pathog. 2017, 109, 214-220. [CrossRef]

93. Fünfhaus, A.; Göbel, J.; Ebeling, J.; Knispel, H.; Garcia-Gonzalez, E.; Genersch, E. Swarming motility and biofilm formation of Paenibacillus larvae, the etiological agent of American Foulbrood of honey bees (Apis mellifera). Sci. Rep. 2018, 8. [CrossRef]

94. Liu, Z.; Zhang, Z.; Qiu, L.; Zhang, F.; Xu, X.; Wei, H.; Tao, X. Characterization and bioactivities of the exopolysaccharide from a probiotic strain of Lactobacillus plantarum WLPL04. J. Dairy Sci. 2017, 100, 6895-6905. [CrossRef]

95. Wang, J.; Zhao, X.; Yang, Y.; Zhao, A.; Yang, Z. Characterization and bioactivities of an exopolysaccharide produced by Lactobacillus plantarum YW32. Int. J. Biol. Macromol. 2015, 74, 119-126. [CrossRef]

96. Silva, L.A.; Lopes Neto, J.H.P.; Cardarelli, H.R. Exopolysaccharides produced by Lactobacillus plantarum: Technological properties, biological activity, and potential application in the food industry. Ann. Microbiol. 2019, 69, 321-328. [CrossRef]

97. Mıdık, F.; Tokatlı, M.; Bağder Elmacı, S.; Özçelik, F. Influence of different culture conditions on exopolysaccharide production by indigenous lactic acid bacteria isolated from pickles. Arch. Microbiol. 2020, 202, 875-885. [CrossRef] [PubMed] 
98. Santarmaki, V.; Kourkoutas, Y.; Zoumpopoulou, G.; Mavrogonatou, E.; Kiourtzidis, M.; Chorianopoulos, N.; Tassou, C.; Tsakalidou, E.; Simopoulos, C.; Ypsilantis, P. Survival, Intestinal Mucosa Adhesion, and Immunomodulatory Potential of Lactobacillus plantarum Strains. Curr. Microbiol. 2017, 74, 1061-1067. [CrossRef] [PubMed]

99. Trunk, T.; Khalil, H.S.; Leo, J.C. Bacterial autoaggregation. AIMS Microbiol. 2018, 4, 140-164. [CrossRef]

100. Schillinger, U.; Guigas, C.; Holzapfel, W. In vitro adherence and other properties of lactobacilli used in probiotic yoghurt-like products. Int. Dairy J. 2005, 15, 1289-1297. [CrossRef]

101. Vinderola, C.G.; Medici, M.; Perdigón, G. Relationship between interaction sites in the gut, hydrophobicity, mucosal immunomodulating capacities and cell wall protein profiles in indigenous and exogenous bacteria. J. Appl. Microbiol. 2004, 96, 230-243. [CrossRef]

102. Ekmekci, H.; Aslim, B.; Ozturk, S. Characterization of vaginal lactobacilli coaggregation ability with Escherichia coli. Microbiol. Immunol. 2009, 53, 59-65. [CrossRef]

103. Bouchard, D.S.; Seridan, B.; Saraoui, T.; Rault, L.; Germon, P.; Gonzalez-Moreno, C.; Nader-Macias, F.M.E.; Baud, D.; François, P.; Chuat, V.; et al. Lactic Acid Bacteria Isolated from Bovine Mammary Microbiota: Potential Allies against Bovine Mastitis. PLoS ONE 2016, 10, e0144831. [CrossRef]

104. Kragh, K.N.; Hutchison, J.B.; Melaugh, G.; Rodesney, C.; Roberts, A.E.L.; Irie, Y.; Jensen, P.Ø.; Diggle, S.P.; Allen, R.J.; Gordon, V.; et al. Role of Multicellular Aggregates in Biofilm Formation. mBio 2016, 7, e00237-16. [CrossRef]

105. Collado, M.C.; Meriluoto, J.; Salminen, S. Adhesion and aggregation properties of probiotic and pathogen strains. Eur. Food Res. Technol. 2008, 226, 1065-1073. [CrossRef]

106. Kaushik, J.K.; Kumar, A.; Duary, R.K.; Mohanty, A.K.; Grover, S.; Batish, V.K. Functional and Probiotic Attributes of an Indigenous Isolate of Lactobacillus plantarum. PLoS ONE 2009, 4, e8099. [CrossRef] [PubMed]

107. García-Cayuela, T.; Korany, A.M.; Bustos, I.; De Cadiñanos, L.P.G.; Requena, T.; Peláez, C.; Martínez-Cuesta, M.C. Adhesion abilities of dairy Lactobacillus plantarum strains showing an aggregation phenotype. Food Res. Int. 2014, 57, 44-50. [CrossRef]

108. Tuo, Y.; Yu, H.; Ai, L.; Wu, Z.; Guo, B.; Chen, W. Aggregation and adhesion properties of 22 Lactobacillus strains. J. Dairy Sci. 2013, 96, 4252-4257. [CrossRef]

109. Smart, M.D.; Otto, C.R.V.; Lundgren, J.G. Nutritional status of honey bee (Apis mellifera L.) workers across an agricultural land-use gradient. Sci. Rep. 2019, 9. [CrossRef] [PubMed]

110. Wang, H.; Liu, C.; Liu, Z.; Wang, Y.; Ma, L.; Xu, B. The different dietary sugars modulate the composition of the gut microbiota in honeybee during overwintering. BMC Microbiol. 2020, 20. [CrossRef] [PubMed]

111. Engel, P.; Moran, N.A. The gut microbiota of insects-diversity in structure and function. FEMS Microbiol. Rev. 2013, 37, 699-735. [CrossRef]

112. Kešnerová, L.; Mars, R.A.T.; Ellegaard, K.M.; Troilo, M.; Sauer, U.; Engel, P. Disentangling metabolic functions of bacteria in the honey bee gut. PLoS Biol. 2017, 15, e2003467. [CrossRef] [PubMed]

113. Engel, P.; Martinson, V.G.; Moran, N.A. Functional diversity within the simple gut microbiota of the honey bee. Proc. Natl. Acad. Sci. USA 2012, 109, 11002-11007. [CrossRef]

114. Zheng, H.; Powell, J.E.; Steele, M.I.; Dietrich, C.; Moran, N.A. Honeybee gut microbiota promotes host weight gain via bacterial metabolism and hormonal signaling. Proc. Natl. Acad. Sci. USA 2017, 114, 4775-4780. [CrossRef]

115. Zheng, H.; Steele, M.I.; Leonard, S.P.; Motta, E.V.S.; Moran, N.A. Honey bees as models for gut microbiota research. Lab Anim. 2018, 47, 317-325. [CrossRef]

116. Gaggia, F.; Baffoni, L.; Alberoni, D. Probiotics for Honeybees' Health. In Probiotics and Prebiotics in Animal Health and Food Safety; Di Gioia, D., Biavati, B., Eds.; Springer International Publishing: Cham, Switzerland, 2018; pp. 219-245. ISBN 978-3-319-71950-4.

117. Kaškonienè, V.; Adaškevičiūtè, V.; Kaškonas, P.; Mickienė, R.; Maruška, A. Antimicrobial and antioxidant activities of natural and fermented bee pollen. Food Biosci. 2020, 34. [CrossRef]

118. Gu, H.; Song, I.-B.; Han, H.-J.; Lee, N.-Y.; Cha, J.-Y.; Son, Y.-K.; Kwon, J. Antioxidant Activity of Royal Jelly Hydrolysates Obtained by Enzymatic Treatment. Korean J. Food Sci. Anim. Resour. 2018, 38, 135-142. [CrossRef]

119. Bogdanov, S.; Jurendic, T.; Sieber, R.; Gallmann, P. Honey for Nutrition and Health: A Review. J. Am. Coll. Nutr. 2008, 27, 677-689. [CrossRef] [PubMed] 
120. Bakour, M.; Al-Waili, N.S.; El Menyiy, N.; Imtara, H.; Figuira, A.C.; Al-Waili, T.; Lyoussi, B. Antioxidant activity and protective effect of bee bread (honey and pollen) in aluminum-induced anemia, elevation of inflammatory makers and hepato-renal toxicity. J. Food Sci. Technol. 2017, 54, 4205-4212. [CrossRef] [PubMed]

121. Machado De-Melo, A.A.; De Almeida-Muradian, L.B.; Sancho, M.T.; Pascual-Maté, A. Composition and properties of Apis mellifera honey: A review. J. Apic. Res. 2018, 57, 5-37. [CrossRef]

122. Escuredo, O.; Míguez, M.; Fernández-González, M.; Carmen Seijo, M. Nutritional value and antioxidant activity of honeys produced in a European Atlantic area. Food Chem. 2013, 138, 851-856. [CrossRef]

123. Michlmayr, H.; Kneifel, W. $\beta$-Glucosidase activities of lactic acid bacteria: Mechanisms, impact on fermented food and human health. FEMS Microbiol. Lett. 2014, 352, 1-10. [CrossRef]

124. Yuksekdag, Z.; Cinar Acar, B.; Aslim, B.; Tukenmez, U. $\beta$-Glucosidase activity and bioconversion of isoflavone glycosides to aglycones by potential probiotic bacteria. Int. J. Food Prop. 2017, 20, S2878-S2886. [CrossRef]

125. Choi, Y.-B.; Kim, K.-S.; Rhee, J.-S. Hydrolysis of soybean isoflavone glucosides by lactic acid bacteria. Biotechnol. Lett. 2002, 24, 2113-2116. [CrossRef]

126. Zheng, H.; Perreau, J.; Powell, J.E.; Han, B.; Zhang, Z.; Kwong, W.K.; Tringe, S.G.; Moran, N.A. Division of labor in honey bee gut microbiota for plant polysaccharide digestion. Proc. Natl. Acad. Sci. USA 2019, 116. [CrossRef]

127. Stanley, D.; Rejzek, M.; Naested, H.; Smedley, M.; Otero, S.; Fahy, B.; Thorpe, F.; Nash, R.J.; Harwood, W.; Svensson, B.; et al. The Role of $\alpha$-Glucosidase in Germinating Barley Grains. Plant Physiol. 2011, 155. [CrossRef] [PubMed]

128. Haydak, M.H. Honey Bee Nutrition. Annu. Rev. Entomol. 1970, 15, 143-156. [CrossRef]

129. Johnson, R.M. Honey Bee Toxicology. Annu. Rev. Entomol. 2015, 60, 415-434. [CrossRef] [PubMed]

130. Barker, R.J.; Lehner, Y. Influence of diet on sugars found by thin-layer chromatography in thoraces of honey bees, Apis mellifera L. J. Exp. Zool. 1974, 188, 157-164. [CrossRef]

131. Zheng, H.; Nishida, A.; Kwong, W.K.; Koch, H.; Engel, P.; Steele, M.I.; Moran, N.A. Metabolism of Toxic Sugars by Strains of the Bee Gut Symbiont Gilliamella apicola. mBio 2016, 7, e01326-16. [CrossRef]

132. Barker, R.J. Some Carbohydrates Found in Pollen and Pollen Substitutes are Toxic to Honey Bees. J. Nutr. 1977, 107, 1859-1862. [CrossRef]

133. Di Pasquale, G.; Salignon, M.; Le Conte, Y.; Belzunces, L.P.; Decourtye, A.; Kretzschmar, A.; Suchail, S.; Brunet, J.-L.; Alaux, C. Influence of Pollen Nutrition on Honey Bee Health: Do Pollen Quality and Diversity Matter? PLoS ONE 2013, 8, e72016. [CrossRef]

134. Tan, K.; Guo, Y.H.; Nicolson, S.W.; Radloff, S.E.; Song, Q.S.; Hepburn, H.R. Honeybee (Apis cerana) Foraging Responses to the Toxic Honey of Tripterygium hypoglaucum (Celastraceae): Changing Threshold of Nectar Acceptability. J. Chem. Ecol. 2007, 33, 2209-2217. [CrossRef]

135. Price, D.R.G.; Karley, A.J.; Ashford, D.A.; Isaacs, H.V.; Pownall, M.E.; Wilkinson, H.S.; Gatehouse, J.A.; Douglas, A.E. Molecular characterisation of a candidate gut sucrase in the pea aphid, Acyrthosiphon pisum. Insect Biochem. Mol. Biol. 2007, 37, 307-317. [CrossRef]

136. Seeburger, V.C.; D’Alvise, P.; Shaaban, B.; Schweikert, K.; Lohaus, G.; Schroeder, A.; Hasselmann, M. The trisaccharide melezitose impacts honey bees and their intestinal microbiota. PLoS ONE 2020, 15, e0230871. [CrossRef]

137. Ricigliano, V.A.; Fitz, W.; Copeland, D.C.; Mott, B.M.; Maes, P.; Floyd, A.S.; Dockstader, A.; Anderson, K.E. The impact of pollen consumption on honey bee (Apis mellifera) digestive physiology and carbohydrate metabolism. Arch. Insect Biochem. Physiol. 2017, 96, e21406. [CrossRef] [PubMed]

138. Lee, F.J.; Rusch, D.B.; Stewart, F.J.; Mattila, H.R.; Newton, I.L.G. Saccharide breakdown and fermentation by the honey bee gut microbiome. Environ. Microbiol. 2015, 17, 796-815. [CrossRef] [PubMed]

139. Lamei, S.; Stephan, J.G.; Riesbeck, K.; Vasquez, A.; Olofsson, T.; Nilson, B.; de Miranda, J.R.; Forsgren, E. The secretome of honey bee-specific lactic acid bacteria inhibits Paenibacillus larvae growth. J. Apic. Res. 2019, 58, 405-412. [CrossRef]

140. Kaznowski, A.; Szymas, B.; Jazdzinska, E.; Kazimierczak, M.; Paetz, H.; Mokracka, J. The effects of probiotic supplementation on the content of intestinal microflora and chemical composition of worker honey bees (Apis mellifera). J. Apic. Res. 2005, 44, 10-14. [CrossRef]

141. Stephan, J.G.; Lamei, S.; Pettis, J.S.; Riesbeck, K.; de Miranda, J.R.; Forsgren, E. Honeybee-Specific Lactic Acid Bacterium Supplements Have No Effect on American Foulbrood-Infected Honeybee Colonies. Appl. Environ. Microbiol. 2019, 85, e00606-19. [CrossRef] 
142. Lamei, S.; Stephan, J.G.; Nilson, B.; Sieuwerts, S.; Riesbeck, K.; de Miranda, J.R.; Forsgren, E. Feeding Honeybee Colonies with Honeybee-Specific Lactic Acid Bacteria (Hbs-LAB) Does Not Affect Colony-Level Hbs-LAB Composition or Paenibacillus larvae Spore Levels, Although American Foulbrood Affected Colonies Harbor a More Diverse Hbs-LAB Community. Microb. Ecol. 2020, 79, 743-755. [CrossRef]

143. Ptaszyńska, A.A.; Borsuk, G.; Zdybicka-Barabas, A.; Cytryńska, M.; Małek, W. Are commercial probiotics and prebiotics effective in the treatment and prevention of honeybee nosemosis C? Parasitol. Res. 2016, 115, 397-406. [CrossRef]

144. El Khoury, S.; Rousseau, A.; Lecoeur, A.; Cheaib, B.; Bouslama, S.; Mercier, P.-L.; Demey, V.; Castex, M.; Giovenazzo, P.; Derome, N. Deleterious Interaction Between Honeybees (Apis mellifera) and its Microsporidian Intracellular Parasite Nosema ceranae Was Mitigated by Administrating Either Endogenous or Allochthonous Gut Microbiota Strains. Front. Ecol. Evol. 2018, 6, 58. [CrossRef]

145. Cozzolino, A.; Vergalito, F.; Tremonte, P.; Iorizzo, M.; Lombardi, S.J.; Sorrentino, E.; Luongo, D.; Coppola, R.; Di Marco, R.; Succi, M. Preliminary Evaluation of the Safety and Probiotic Potential of Akkermansia muciniphila DSM 22959 in Comparison with Lactobacillus rhamnosus GG. Microorganisms 2020, 8, 189. [CrossRef]

(C) 2020 by the authors. Licensee MDPI, Basel, Switzerland. This article is an open access article distributed under the terms and conditions of the Creative Commons Attribution (CC BY) license (http://creativecommons.org/licenses/by/4.0/). 